\title{
REINTERPRETASI DAN SINERGITAS TEORI PENCIPTAAN ALAM
}

\author{
Ilhamuddin \\ Fakultas Dakwah dan Komunikasi IAIN Sumatera Utara \\ Jl. Willem Iskandar Pasar V Medan Estate, Medan 20371 \\ e-mail: ilhamnasution71@yahoo.com
}

\begin{abstract}
Abstrak: Ilmuwan-ilmuwan modern telah berusaha mengkaji hakikat alam dengan beragam pendekatan. Teori-teori mereka tentang penciptaan alam didasari dan dipengaruhi oleh paradigma keilmuan masing-masing, dan terkadang perbedaan pendekatan telah memunculkan beragam penafsiran tentang eksistensi. Sebagian ahli memiliki kecenderungan membenturkan beraneka teori tentang penciptaan alam, dan menilai bahwa semua teori tersebut memiliki beragam kontradiksi. Lewat artikel ini, penulis melakukan reinterpretasi terhadap hakikat teori para ahli tentang penciptaan alam dan menemukan sinergitas antara teori-teori mereka. Penulis menegaskan bahwa tidak ada kontradiksi antara teori saintis, teolog, filsuf dan mufasir tentang penciptaan alam. Dengan demikian, teori teologi, filsafat dan sains dapat mengokohkan doktrin agama tentang alam semesta. Lebih penting lagi, artikel ini mengokohkan pendapat bahwa tidak ada pertentangan antara temuan akal dan informasi wahyu.
\end{abstract}

\begin{abstract}
Reinterpretation and Synergetic Theory of the Creation of the Universe. Modern scholars have made all due efforts to study the essence of the universe through a variety of approaches. Their theory on the creation of the universe is based on respective science paradigm, and at times different approach has led into distinct interpretation on the existence. Many an expert tents to conflict various theories of the creation of the universe, and conclude that those theories contradict one another. Through this article, the author reinterprets the focal point of such theories on the creation of the universe, and finds the synergy amongst those theories. In addition, he asserts that there is no contradiction between theories found within the boundaries of scientist, theologian, philosophers and the exegetes on the creation of the universe, and therefore, every single theory may support the truth of religious doctrine on the cosmos. What's more, this article affirms the view that there is no contradiction between the findings of the intellect and the Divine information.
\end{abstract}

Kata Kunci: teori penciptaan alam, pemikiran Islam, teologi, filsafat, sains, tafsir 


\section{Pendahuluan}

Masalah penciptaan alam ternyata telah menarik perhatian banyak kalangan, mulai dari ilmuan, mutakallimin atau teolog sampai filosof. ${ }^{1}$ Agama juga mempunyai andil besar dalam memberikan informasi mengenai masalah ini. Sesuai bidang kajiannya, ilmuan merespon masalah ini dengan pendekatan fisika. Mutakallimin atau ahli kalam (teolog) merespon dengan pendekatan teologi dan filosof merespon dengan pendekatan filsafat. Sedangkan agama memberikan informasi melalui kitab suci, sebagaimana dilukiskan dalam bentuk kalimat yang bersifat imperatif (memerintahkan). Misalnya dalam al-Qur'an ditemukan ayat-ayat yang di dalamnya terdapat kata كن فيكــــ (jadilah maka jadilah ia). ${ }^{2}$ Dalam Perjanjian Lama ditemukan perkataan: "Berfirmanlah Allah: Jadilah maka jadilah ia". ${ }^{3}$ Kalimat كن فيكـــ (jadilah maka jadilah ia) di samping dapat dipahami sebagai bagian dari rahasia Allah dalam hal penciptaan, adalah juga sekaligus merupakan ungkapan praktis yang dapat ditangkap nalar manusia untuk mendekati makna penciptaan dari tidak ada mnjadi ada.

Rumusan dari masing-masing kalangan tersebut di atas melahirkan berbagai teori. Ilmuan melalui pendekatan sains melahirkan teori big bang dan expanding universe. Mutakallimin atau teolog melahirkan teori الميـــــــــ (al-hayula) atau atomisme dan الكمون (al-kummun). Sedangkan filosof melahirkan teori الفيـــــ (emanasi). Agama menginformasikan doktrin كن فيكــــ (kunfayakun).

Tampaknya, sinergitas ${ }^{4}$ antara berbagai teori dan doktrin agama tersebut konstruktif bagi upaya peningkatan keimanan, terutama bagi kalangan intelektual, yang jika berpegang pada pendapat rasio dan bukti empiris semata rentan terjerumus pada paham ke-qadiman alam fisik dan pengingkaran alam metafisik sebagaimana pesan yang terkandung dalam hipotesa-Lavoisier yang berbunyi "Rien ne se cree, rien ne se perd", artinya "tiada sesuatu dapat terjadi dari ketiadaan (kehampaan) dan tiada pula sesuatu yang melenyapkan dalam ketiadaan". 5

Berbagai teori penciptaan alam yang telah disebut di atas dapat dipahami sebagai saling melengkapi, atau paling tidak seperti disimpulkan oleh Maurice Bucaille tatkala

${ }^{1}$ Ilmuan atau saintis, teolog (Mutakallimin atau Ahl al-Kalâm) dan filosof adalah samasama kelompok pemikir. Namun, objek kajian masing-masing berbeda. Objek kajian ilmu adalah dunia fisik yang realistis, sedangkan objek kajian teologi dan filsafat adalah dunia metafisik yang spekulatif. Dalam pada itu, pemikiran spekulatif para Teolog berada di bawah ajaran agama samawi sedangkan pemikiran spekulatif filosof tidak dibatasi agama. Lihat Philip K. Hitti, History of The Arabs (London: The MacMillan Press LTD, London, 1974), h. 369-373.

${ }^{2}$ Al-Qur'an, surat al-Anbiyâ'/21: 30.

${ }^{3}$ Kitab Kejadian, pasal 1, ayat 3-4.

${ }^{4}$ Term "sinergitas" dapat diartikan sebagai gabungan. Lihat Pusat Bahasa Departemen Pendidikan Nasional, Kamus Besar Bahasa Indonesia (Jakarta: Balai Pustaka, 2001), h. 1070.

${ }^{5}$ Malik bin Nabi, Fenomena al-Qur'an, terj. Saleh Mahfoed (Bandung: PT. Al-Ma'arif, 1983), h. 240 . 
ia meneliti relasi sains dan al-Qur'an, tidak kontradiktif atau sesuai dengan al-Qur'an. ${ }^{6}$ Umpamanya, oleh karena berangkat dari pendekatan fisika, maka teori penciptaan alam di kalangan ilmuan hanya dapat dipahami sebagai sesuatu peristiwa yang dimulai dari aspek material saja sehingga dikatakan penciptaan alam berasal dari dentuman besar (big bang) dari gumpalan benda raksasa, yang sudah berupa materi, jisim atau benda. Teori ini menyisakan misteri tentang asal muassal gumpalan materi raksasa tersebut sampai dapat dikaitkan dengan Tuhan yang immaterial. Namun, misteri ini dapat ditemukan jawabannya pada teorinya para mutakallimin atau teolog, filosof dan doktrin agama.

Kaum Asy'ariyah dengan teori atomnya menyebut adanya الفيــــــــــ (al-hayula), yaitu sesuatu yang niskala, berupa materi yang belum dapat diamati karena belum memiliki bentuk. Sementara itu, kaum Muktazilah mengetengahkan teori الكمون (al-kummun), yaitu sesuatu yang tersimpan atau tersembunyi. Dapat dipahami bahwa sesuatu yang belum berbentuk pastilah tersembunyi dari pengamatan.

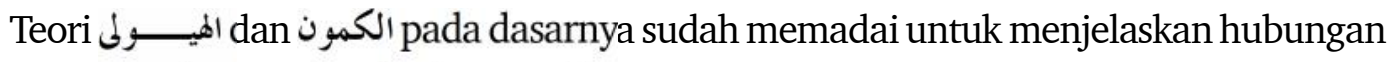
Tuhan dengan alam. Dalam kedua teori ini, dipahami bahwa Allah sebagai sesuatu yang immaterial, di dalam menciptakan alam, tidak berhubungan langsung dengan alam semesta yang material tetapi dibatasi oleh sesuatu yang juga immaterial berupa perintah dalam bentuk $\mathbf{S}$ yang ditujukan kepada sesuatu yang juga immaterial berupa potensi yang hanya ada dalam ilmu dan iradah Allah sehingga terciptalah الهيـــــــ لم immaterial. Dengan rumusan seperti ini, tampaknya mutakallimin memandang doktrin التوحيــــ (keesaan Tuhan) dalam sudah tidak terganggu.

Al-Qur'an-lah yang memberikan penjelasan mengenai masa penciptaan alam dan penomena terciptanya kehidupan di alam tersebut. Dalam ayatnya difirmankan Allah bahwa penciptaan Bumi adalah dua masa, sebagaimana disebutkan dalam surat Fushshilat (41) ayat 9. Selanjutnya diinformasikan bahwa jumlah masa penciptaan langit dan bumi adalah enam masa, sebagaimana disebutkan dalam surat al-A'raf (7) ayat 54; surat Yunus (10) ayat 3; surat Hud (11) ayat 7; surat al-Furqan (25) ayat 59; surat al-Sajadah (32) ayat 4; surat al-Hadid (57) ayat 4; dan surat Qaf (50) ayat 38. Sedangkan segala sesuatu yang hidup dikatakan dijadikan dari air, sebagaimana disebutkan dalam surat al-Anbiya' (21) ayat 30.

Demikianlah berbagai teori dan doktrin penciptaan dalam berbagai formulasinya, yang antara satu dan lainnya dapat dipandang sebagai saling melengkapi karena apapun yang ada maupun yang terjadi dalam kehidupan ini pada hakekatnya tidak ada yang kontradiktif meskipun sepintas lalu, tampak dipermukaan, menurut manusia dipahami ada pertentangan. Sesungguhnya tidak ada pertentangan dalam ciptaan Allah, yang ada adalah pasang-pasangan atau perimbangan-perimbangan dan perbandingan-perbandingan yang menunjukkan adanya keteraturan yang dapat diikuti atau penyimpangan yang berakibat rusaknya keteraturan itu sehingga harus dijauhi. Misalnya, iman dan kufur itu bukanlah pertentangan tetapi perbandingan antara aturan yang dapat diikuti dan larangan yang harus dijauhi.

${ }^{6}$ Maurice Bucaille, La Bible, le Coran et la Science (Sengers, Paris, 1976). 
Demikian pula halnya dalam dunia pemikiran. Perbedaan dalam pemikiran seyogianya tidak mesti selalu dimaknai sebagai pertentangan, meskipun boleh jadi di permukaan tampak sebagai pertentangan tetapi sering kemudian berakhir sebagai sesuatu yang saling melengkapi.Umpamanya, mengenai berapa kalikah Allah menciptakan alam semesta ini, yang dalam hal ini antara Asy'ariyah dan Muktazilah berbeda pendapat.

Di satu pihak, Asy'ariyah mengatakan bahwa Allah menciptakan alam semesta ini berkali-kali bahkan setiap saat tanpa henti. Sementara di pihak lain, Muktazilah mengatakan bahwa Allah menciptakan alam ini hanya sekali saja.

Kedua pendapat tersebut tampak di permukaannya berbeda bahkan bertentangan

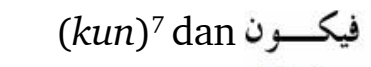

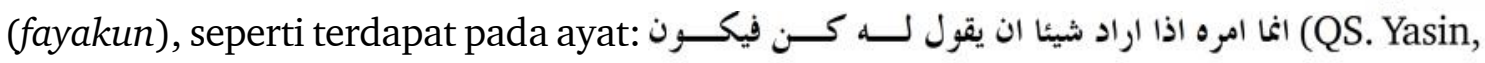
36: 82). Kata Seperti ini selain dijumpai pada surat Yasin ayat 82, juga dapat dijumpai dalam banyak ayat al-Qur'an dengan konteknya yang bervariasi.

Dengan demikian pada dasarnya yang terjadi di antara Muktazilah dan Asy'ariyah dalam diskursus penciptaan alam adalah perbedaan jalan pikiran saja bukan pertentangan. Hasil pemikiran keduanya tetap sama-sama tersahuti oleh lafaz كن فيكـــ sebagaimana terdapat dalam al-Qur'an. Untuk lebih jelasnya, uraian berikut ini mengetengahkan berbagai pendekatan teori penciptaan alam, mulai pendekatan sains, teologi, filsafat dan al-Qur'an.

\section{Konsep Sains tentang Penciptaan Alam}

Pendakatan sains dalam masalah penciptaan alam bermula pada tahun 1929, Edwin Powell Hubble (1889-1953), astronom Amerika, mengemukakan teori expanding universe, yakni teori mengembang dengan kesimpulan bahwa galaxi-galaxi di sekitar Bimasakti menjauhi Bumi dengan kecepatan yang sebanding dengan jaraknya dari Bumi. Galaxi yang lebih jauh kecepatannya lebih besar. ${ }^{8}$

Berikutnya, seorang ahli fisika nuklir dan kosmologi kelahiran Rusia, yang separoh hidupnya berada di Amerika, bernama George Gamow (1904-1968) pada tahun 1952 berkesimpulan bahwa galaxi-galaxi di seluruh jagad raya berjumlah sekitar 100 milyar dan rata-rata masing-masing berisi pula 100 milyar bintang. ${ }^{9}$

Awalnya, galaxi-galaxi dan bintang-bintang tersebut berada di satu tempat bersamasama dengan bumi sekitar 15 milyar tahun silam. Materi sebanyak itu terkumpul sebagai

${ }^{7}$ Ketika memulai menciptakan alam semesta Allah mengatakan $\mathbf{S}$ (jadilah) dan ketika Allah akan menghancurkan alam Allah juga akan mengatakan Smaka berakhirlah alam semesta. Lihat Muhammad Mutawally Sya'rawi, Tafsir Sa'rawi, terj. Zainal Arifin, et al., Jilid. 4 (Medan: Duta Azhar), h. 330-331.

${ }^{8}$ PT. Ichtiar Baru Van Hoeve, Ensiklopedi Islam, Jilid II (Yogyakarta: PT. Ichtiar Baru Van Hoeve, 1997), h. 18.

${ }^{9} \mathrm{Ibid}$. 
suatu gumpalan neutron. Gumpalan neutron ini terbentuk dari elektron-elektron yang berasal dari masing-masing atom yang telah menyatu dengan protonnya sehingga tidak memiliki gaya tolak listrik antara masing-masing elektron dan masing-masing proton. Gumpalan ini berada dalam alam dan tanpa diketahui sebab musabbabnya meledak dengan sangat dahsyatnya sehingga terhamburlah seluruh materi itu ke seluruh ruang jagad sara. Peristiwa ini selanjutnya dikenal dengan sebutan teori big bang (dentuman besar). ${ }^{10}$

Gumpalan sebesar apa yang disebut di atas, sudah barang tentu tidak pernah bergelimangan di ruang kosmos sebab gaya gravitasi gumpalan itu akan begitu besar sehingga ia akan tergencet menjadi sangat kecil, lebih kecil daripada bintang pulsar yang jari-jarinya hanya sebesar dua sampai tiga kilometer dan massanya kira-kira dua atau tiga kali massa sang surya, bahkan lebih kecil dari black hole (ruang hitam) yang massanya jauh melebihi pulsar dan jari-jarinya menyusut mendekati ukuran titik. ${ }^{11}$

Tidak bisa dibayangkan berapa besar kepadatan materi dalam titik yang volumenya nol itu jika seluruh massa 100 milyar x 100 milyar bintang sebesar matahari dipaksakan masuk di dalamnya. Inilah yang sering disebut dengan singularitas. Jadi, konsep dentuman besar terpaksa dikoreksi, yaitu bahwa bagaimana bisa keberadaan alam semesta ini diawali oleh ledakan mahadahsyat ketika tercipta ruang-waktu. Demikian pula bagaimana bisa ada energi dengan suhu yang tidak terkirakan tingginya keluar dari singularitas. ${ }^{12}$

Para ahli berpendapat bahwa alam semesta tercipta dari ketiadaan, sebagai goncangan vakum yang membuatnya mengandung energi yang sangat tinggi dalam singularitas yang tekanannya menjadi negatif. Vakum yang mempunyai kandungan energi yang luar biasa besarnya serta tekanan gravitasi yang negatif ini menimbulkan dorongan eksplosif keluar dari singularitas. ${ }^{13}$

Tatkala alam mendingin karena ekspansinya sehingga suhunya merendah melewati 1000 trilyun-trilyun derajat, pada umur 10-35 sekon, lalu terjadilah gejala "lewat dingin". Pada saat pengembunan tersentak, keluarlah energi yang memanaskan kosmos kembali menjadi 1000 trilyun-trilyun derajat. Lalu seluruh kosmos terdorong membesar dengan kecepatan luar biasa selama waktu 10-35 sekon. Ekspansi luar biasa cepatnya ini menimbulkan kesan seakan-akan alam kita digelembungkan dengan tiupan dahsyat sehingga dikenal dengan gejala inflasi. ${ }^{14}$

Selama proses inflasi itu, kemungkinan tidak hanya satu alam saja yang muncul. Bisa beberapa alam dengan hukumnya sendiri-sendiri dan tidak harus sama antara satu dan lainnya. Oleh karena materialisasi dari energi yang tersedia, yang berakibat terhentinya

${ }^{10}$ Ibid., h. 19.

${ }^{11}$ Ibid.

${ }^{12}$ Ibid.

${ }^{13}$ Ibid.

${ }^{14}$ Ibid. 
inflasi, tidak terjadi secara serentak, maka dilokasi-lokasi tertentu terdapat konsentrasi materi yang merupakan benih-benih galaxi yang tersebar di seluruh kosmos. ${ }^{15}$ Jalan pikiran sains tentang terciptanya alam ini dapat dilihat pada tabel berikut:

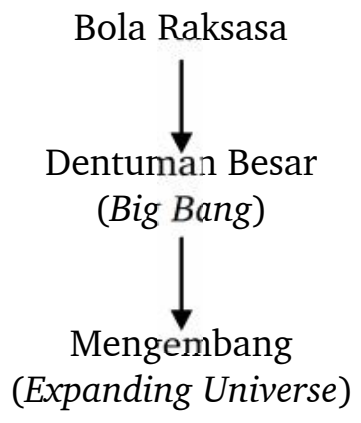

Tabel di atas jelas menunjukkan keterbatasan sains di dalam memberikan penjelasan tentang sesuatu di luar fisika, atau apa yang ada atau yang terjadi sebelum terbetuknya materi bola raksasa, sehingga teori big bang maupun expanding universe bahkan sains yang umumnya berkembang di dunia Barat, tidak dapat memberi saluran pemikiran yang dapat mengantarkan pemikiran seseorang sampai ke Tuhan. Inilah agaknya yang mendasari kegelisahan ilmuan muslim seperti Syed Muhammad Naquib al-Attas sehingga berupaya memasukkan dimensi metafisis di dalam wacana sains Islam. ${ }^{16}$

Metafisika Islam rumusan al-Attas dapat dipandang sebagai restatement dari rumusan pemikir muslim klasik, terutama di kalangan sufi, karena bagi al-Attas metafisika Islam merupakan kebenaran yang sudah disepakati sejak awal peradaban Islam masa lalu. Uraiannya meliputi pandangan ontologis dan kosmologis yang ditawarkan sebagai basis sains yang relevan dengan pandangan dunia Islam. ${ }^{17}$

Teori penciptaan alam dalam sains, sebagaimana tergambar pada tabel di atas tidak menjelaskan saluran yang dapat mengantarkan fikiran, tentang terciptanya alam, terhubung sampai ke Tuhan. Oleh karena itu, dalam teori sains ada saluran pemikiran yang terputus antara alam dan Tuhan, sehingga seolah-olah alam tercipta dengan sendirinya. Dalam konteks seperti ini, eksistensi Tuhan terabaikan. Tampaknya, hal ini disebabkan oleh sifat sains

${ }^{15}$ Ibid.

${ }^{16}$ Gagasan atau ide-ide Syed Muhammad Naquib al-Attas tentang sains Islam secara umum, atau metafisika Islam secara khusus, sangat potensial untuk dipertimbangkan dalam wacana relasi agama dan sains dalam Islam. Tidak terkecuali dalam menata pendirian UniversitasUniversitas Islam, seperti UIN yang sedang mewabah di lingkungan masyarakat IAIN di Indonesia belakangan ini. Buku yang dapat dijadikan referensi dalam wacana metafisika Islam mode alAttas antara lain Syed Muhammad Naquib al-Attas, A Commentary on Hujjat al-Shiddiq of Nur al-Din al-Raniry (Kuala Lumpur: Ministry of Culture, 1986); Syed Muhammad Naquib al-Attas, Islam and the Philosophy of Science (Kuala Lumpur, ISTAC, 1989); Syed Muhammad Naquib al-Attas, Islam and Secularism (Kuala Lumpur, ISTAC, 1978);

${ }^{17}$ Ach. Maimun Syamsuddin, Integrasi Multidimensi Agama \& Sains (Jogjakarta: IRCiSoD, 2012, h. 187. 
yang hanya dapat mengamati aspek material tidak sampai pada aspek immaterial. Materi dalam kontek ini adalah bola raksasa yang kemudian meledak (big bang) tanpa dapat dijelaskan oleh sains itu sendiri sebab musabbabnya. Selanjutnya, mengembang (expanding universe) yang menjadikan materi-materi yang berasal dari ledakan itu saling menjauh.

Berkaitan penemuan sains dan hukum alam di atas, tampaknya informasi agama yang terdapat dalam al-Qur'an tentang ayat-ayat kauniyah semakin tidak terbantahkan kebenarannya. Dalam kontek itulah maka al-Qur'an menjadi kekuatan bagi Islam, bahkan bagi dunia, meskipun sebagai agama ia datang ke dunia tanpa dilatari oleh sains dan filsafat, namun mampu menjelaskan banyak hal secara ilmiah dan filosofis.

Dari segi objek, agama dan sains berbeda karena objek sains adalah dunia fisika (alam syahadah), fakta empiris atau hal-hal lahiriyah dengan ragam variasinya. Termasuk di dalamnya hal yang sepintas lalu kelihatannya gaib atau bathiniyah, seperti medan magnet atau gravitasi dan kenyataan-kenyataan lain yang menjadi bahan kajian fisika subatomik dan fisika baru lainnya.

Di dalam al-Qur'an terdapat sejumlah ayat yang berisi informasi tentang alam. Agaknya, terkait ini pulalah tampaknya para Teolog dan Filosof muslim menaruh perhatian serius terhadap persoalan teori penciptaan alam. Mereka menaruh perhatian besar terhadap persoalan tersebut dikarenakan satu alasan, yakni untuk memproteksi doktrin التوحيــــــــ (al-tauhid) dari gangguan pemikiran yang dapat merusak keyakinan umat Islam. Misalnya, saluran yang terputus antara alam dan Tuhan dalam teori sains di atas adalah potensial merusak keyakinan umat Islam. Sehubungan dengan hal tersebutlah para Mutakallimin dan Filosof mengemukakan rumusan tentang penciptaan alam.

Secara teologis, masalah penciptaan alam berhubungan erat dengan masalah keyakinan atau aqidah, jika masalah ini dipersepsi secara tidak benar dapat melahirkan pemahaman dan keyakinan yang keliru sehingga menjerumuskan umat Islam. Secara filosofis, masalah penciptaan alam tidak hanya berhubungan dengan masalah alam fisik tetapi juga alam metafisik, jika masalah ini dipersepsi secara tidak benar juga dapat melahirkan pemahaman dan pemikiran yang keliru sehingga menjerumuskan umat Islam. Oleh karena itu, persoalan penciptaan alam merupakan kebutuhan yang sangat urgen bagi umat Islam baik scara teologis maupun secara filosofis.

\section{Konsep Teolog tentang Penciptaan Alam}

Kalangan Teolog muslim atau Mutakallimin secara teoretis telah dapat menghubungkan persoalan penciptaan alam semesta, yang terdiri dari materi dan immateri, dengan Allah sebagai penciptanya yang immaterial tanpa merusak konsep pemahaman manusia terhadap keesaan Allah.

Dalam al-Qur'an terdapat sejumlah ayat yang jika dilihat dari zahir (lahir)nya memberi pengertian seakan-akan Allah mempunyai jisim. Misalnya, dalam al-Qur'an surah al- 


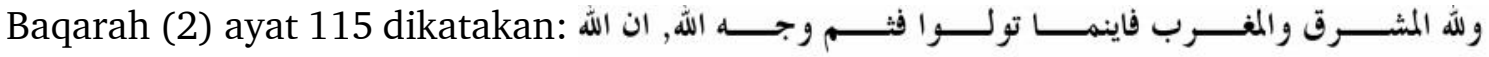
(dan kepunyaan Allah-lah timur dan barat, maka kemanapun kamu menghadap disitulah wajah Allah, ssungguhnya Allah maha luas lagi maha mngetahui. QS.al-Baqarah,2:115). Ayat ini menggunakan term wajah untuk Allah yang secara zahir menggambarkan bahwa seakan-akan Allah mempunyai wajah.

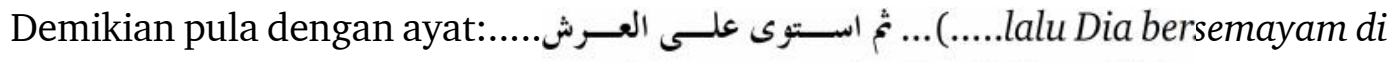
atas 'arasy...QS.al-A'raf,7:54) yang seakan-akan menggambarkan bahwa Allah mempunyai tahta. Juga ayat: ..... . فســبحن الــذى بيـــ.... (maka mahasuci Allah yang di tanganNya.... QS.Yasin,36:83) seakan-akan memberi gambaran b̉ahwa Allah mempunyai tangan.

Bagi kalangan Teolog Muslim, pemahaman terhadap Allah merupakan prinsip yang paling mendasar di dalam aqidah. Oleh karena itu, dibutuhkan rumusan yang tepat di dalam menginterpretasi teks-teks nash yang berbicara mengenai Allah dan berbagai masalah yang berkaitan denganNya.

Prinsip utama dalam aqidah Islamiyah adalah التوحيـــــ التـــ sehingga para teolog atau ulama Mutakallimin menempatkan التوحيــــ sebagai doktrin pokok di dalam ajaranajarannya. Semua Teolog Muslim berupaya mengawal doktrin التوحيــــــ ini dan berpegang teguh kepada keyakinan akan keesaan Allah. Namun, meskipun sama-sama berpaham tetapi tidak jarang jika masing-masing mempunyai jalan pikiran yang berbeda-

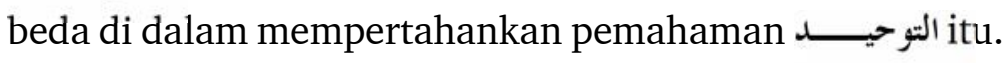

Dalam kaitan itu pula dapat dikatakan bahwa meskipun para ulama Mutakallimin dengan berbagai aliran-alirannya sama-sama beriman kepada al-Qur'an, namun mereka adakalanya berbeda di dalam memahami sebagian ayat-ayatnya sebagaimana disebut di atas.

Bagi kaum Muktazilah, Tuhan adalah sesuatu yang immateri sehingga tidak dapat dikatakan bahwa Allah mempunyai wujud jasmani. Oleh karena itu, teks ayat-ayat al-Qur'an yang mengaitkan Allah dengan term-term jasmani (الجســــ) tak dapat tidak mesti dipahami secara metaforis atau majazi.

Oleh karena itu, maka tatkala term الوجه sebagai muka ketika dihubungkan dengan Tuhan secara metaforis dapat diartikan menjadi zat dan term الكعرش sebagai tahta maupun إيد sebagai tangan ketika dihubungkan dengan Tuhan secara metaforis dapat diartikan menjadi kekuasaan. Jika term-term tersebut diartikan secara harfiyah tentu membawa pemahaman bahwa Allah itu mempunyai jisim. Kaum Muktazilah menolak pemahaman

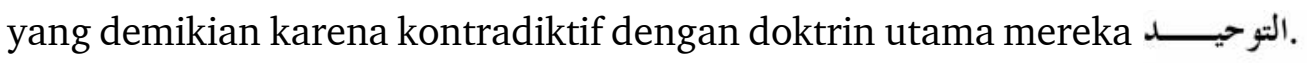

Kaum Asy'ariyah juga tidak menerima jika dikatakan Tuhan mempunyai jisim dan mempunyai sifat-sifat jasmani seperti manusia. Sebagai kelompok yang cenderung menghindar dari persoalan-persoalan rumit, maka di dalam mengartikan term-term الجسسـمة (mujassimah) atau anthropomorfis seperti اليرش , الوجد, dan dalam ayat-ayat yang telah dikemukakan di atas, mereka menempuh cara mudah dengan tetap mengartikannya dengan muka untuk 
العرش dan tangan untuk الريد tahta untuk . Dengan catatan bahwa muka, tahta dan tangan Allah tidak sama dengan muka, tahta dan tangannya manusia ataupun makhlukmakhlukNya yang lain. Bagi mereka mengartikan term-term الجُســـ (mujassimah) atau

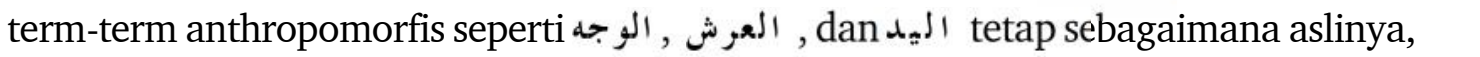
كف yakni tidak boleh diberi interpretasi lain.

Meskipun di atas dikatakan bahwa kaum Asy'ariyah merupakan kelompok yang tidak cenderung berpikir rumit, namun mereka juga mempunyai teori mengenai jisim yang membutuhkan penalaran yang serius. Teori tersebut adalah teori atom yang merupakan jawaban mereka terhadap persoalan berapa kalikah Allah menciptakan jisim, yaitu alam semesta yang majemuk atau جئي ـini, sebagaimana juga telah disinggung di atas.

Atomisme Asy'ariyah memberi pemahaman bahwa alam atau jisim berasal dari sesuatu yang niskala, berupa sesuatu yang belum berbentuk. Dalam kontek ini, alam cosmos yang di dalamnya termasuk yang bersifat materi seperti hewan, tetumbuhan, dan manusia, maupun yang bersifat immateri seperti jin dan malaikat dan seluruh jagad raya ini adalah berasal dari partikel-partikel terkecil yang tidak dapat dibagi, disebut molekul, atom, الجوو هر atau الذرة (al-zarrah).

Atom adalah sesuatu yang tidak berbentuk sehingga tidak dapat diamati. Setiap saat atom atau العحو هر ا (substansi) dapat bersatu sehingga muncullah (aradh). Perpaduan antara atom atau لجحو هر العر ض (substansi) dan (sifat) terbentuklah jisim (tubuh) yang dapat diamati. Perpaduan inilah yang disebut proses penciptaan alam. Hal ini berlaku terus menerus setiap saat tanpa henti.

Teori tersebut di atas menegaskan pemahaman, bahwa Allah swt. menciptakan alam setiap saat, karena jika Dia berhenti menciptakan, maka alam dan semua yang ada di dalamnya akan musnah. Konsekuensi dari teori ini adalah bahwa apa saja yang terjadi di alam ini adalah ciptaan Allah secara langsung berupa terjadinya penggabungan الذرة (al-zarrah) dan penggantian العر ض (al-'aradh). Dalam kontek ini tidak berlaku hukum alam sebagaimana sesuatu yang berjalan sendiri secara konsisten atau tetap. Bagi kaum Muktazilah, setelah alam tercipta alam berjalan sendiri dengan hukum-hukumnya secara konsisten. Konsekuensinya, penciptaan alam ini adalah sekaligus secara bersamaan. Teori ini dikenal dengan teori الكمون (al-kummun), artinya tersembunyi atau tersimpan. Tokoh Muktazilah yang mengemukakan teori ini adalah Al-Nazzam (w.231 H.).

Dalam teori كمون (kummun), Muktazilah memberikan pemahaman bahwa Tuhan menciptakan manusia, hewan, tumbuh-tumbuhan dan jisim-jisim di alam ini sekaligus. Untuk dapat dicermati dengan baik di bawah ini dikemukakan beberapa ayat al-Qur'an yang berbicara tentang penciptaan:

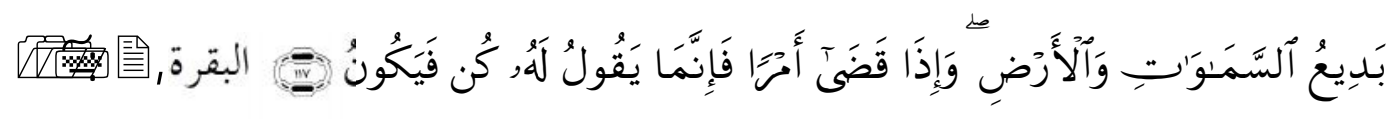




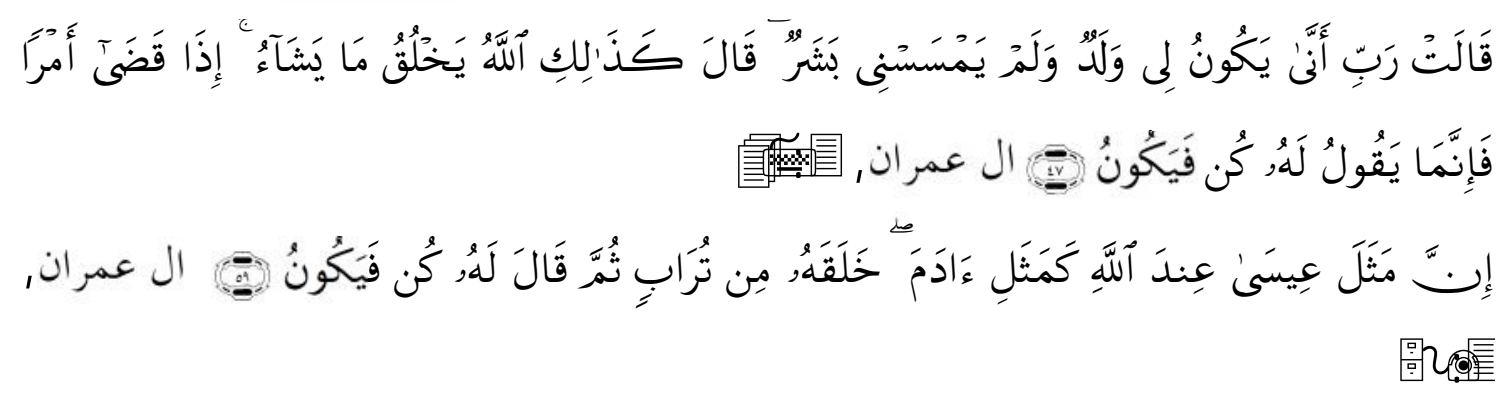

Ayat-ayat di atas menunjukkan bahwa kata كن فيكـــــ (jadilah maka jadilah ia)

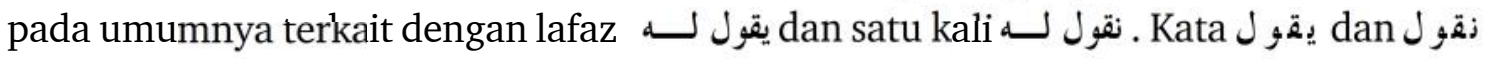

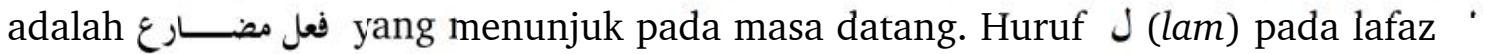

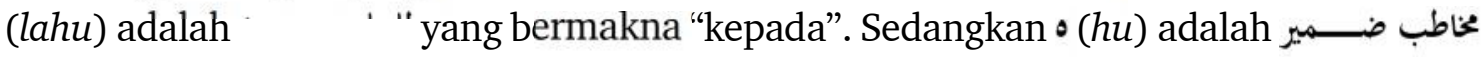
(dhamir mukhathab/kata ganti nama yang diajak bicara) yang menunjuk pada sesuatu yang telah ada sehingga pada ayat-ayat semacam ini kata كن فيكـــــ tampaknya lebih tepat dihubungkan dengan proses "kejadian" dari pada "penciptaan" kalau penciptaan dimaknai sebagai adanya sesuatu dari tidak ada.

Berbagai ayat al-Qur'an juga menginformasikan adanya unsur alam yang menjadi asal dari makhluk, seperti manusia dari tanah dan iblis dari api (Q.S. al-A'râf/7: 12; Q.S. 38: 76), semua jenis hewan dari air (Q.S.al-Nûr/24: 45).

Di dalam ayat-ayat di atas, Allah juga menggunakan kata benda نكرة (nakirah) seperti kata شيء (syai') yang boleh jadi adalah sesuatu yang telah ada namun hanya dalam ilmu Allah, luput atau tak terjangkau oleh ilmu manusia, atau sesuatu yang ada dan diketahui manusia tetapi tidak dapat diamati oleh manusia seperti الميـــــــــ dalam atomisme Asy'ariyah atau juga sesuatu yang tersimpan dan tersembunyi seperti dalam teori كمون (kummun) Muktazilah.

Selanjutnya dapat dikemukakan bahwa di antara lafaz يقـــ pada ayat-ayat di atas terdapat satu ayat yang tidak disertai kata $\boldsymbol{d}$, yaitu ayat 73 pada surat al-An'âm

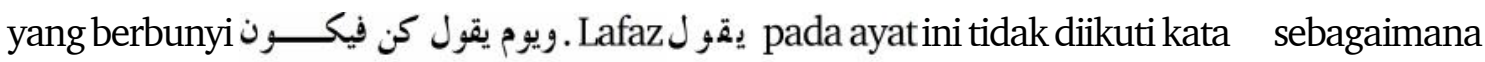
pada ayat-ayat lainnya, sehingga dapat membawa pemahaman bahwa boleh jadi kata $\checkmark$ pada ayat inilah sesungguhnya yang dapat dikategorikan sebagai penciptaan alam dari tidak ada menjadi ada (من العدم الى الوجــــــ), sehingga langit dan bumi yang disebut di awal ayat tersebut adalah diciptakan Tuhan dari tiđak ada menjadi ada.

Jika pemahaman seperti tersebut di atas yang dipakai, maka statement Muktazilah bahwa penciptaan alam hanya sekali saja dapat dipandang mempunyai kekuatan sekaligus mempertegas dan memperkuat doktrin tauhid tentang ke-Esa-an, ke-qadim-an, ke-muthlaqan dan ke-azali-an Allah. Kemudian dapat menolak pendapat yang meng-qadim-kan alam karena alam diciptakan dari tidak ada sehingga alam ini sesungguhnya baharu. Hal ini relevan dengan makna penciptaan sebagai الايجاد مــن العــدم الى الوجــــ (penciptaan dari tidak ada menjadi ada). 
Jika demikian halnya, jalan pikiran yang mengatakan bahwa penciptaan alam terjadi sekali saja sebagaimana pendapat Muktazilah menjadi semakin kuat. Lalu selebihnya adalah penciptaan susulan. Penciptaan susulan ini oleh Muktazilah tidak lagi dimaknai sebagai penciptaan tetapi sebagai kejadian-kejadian yang diatur berdasarkan sunnatullah yang berlangsung secara konsisten sebagaimana diisyaratkan dalam ayat: ولن تجسـ لســــ الله تبـــ (Dan kamu sekali-kali tiada akan mendapat perubahan pada sunnatullah. QS.al-Ahzâb/33: 62; al-Fathly/48: 23).

Pendapat Muktazilah membawa kepada pemahaman bahwa penciptaan Nabi Adam as. tidak berarti lebih dulu dari Nabi Muhammad saw. dan begitu juga manusia abad 21 sekarang. Dengan pengertian, bahwa ketika Adam as. muncul, manusia lainnya yang akan muncul belakangan masih disimpan dalam tempat persembunyiannya atau kegaibannya di alam metafisik. Pada waktu manusia lainnya muncul, kemunculan tersebut tetap berada dalam lingkup pengetahuan dan pengawasan Allah swt. sehingga tidak ada sesuatupun baik جوج (material), yakni yang ada maupun عرض (accidental), yakni yang terjadi, lepas atau diluar pengetahuan dan pengawasan Allah swt.

Berdasarkan penjelasan di atas dapat ditegaskan bahwa dalam memproteksi doktrin التوحيــــ atomisme Asy'ariyah menggunakan pemahaman bahwa Allah menciptakan alam secara langsung setiap saat terus menerus tanpa henti sehingga Allah swt. dipersepsi sebagai zat yang aktif dan indevenden sementara alam sebagai ciptaanNya merupakan wujud yang pasif. Dalam kontek ini, doktrin التوحيـــــ Asy'ariyah menempatkan Allah sebagai wujud zat yang mandiri, bebas dan aktif seaktif-aktifNya. Sedangkan alam merupakan wujud zat yang pasif se-pasif-pasifnya. Penekanan doktrin التوحيـــ dalam kontek ini adalah pada keaktifan Allah dan kepasifan alam.

Sementara itu, dalam memproteksi doktrin التوحيـــــ teori kummun Muktazilah menggunakan pemahaman bahwa Allah menciptakan alam semesta sekaligus secara bersamaan. Allah dalam kontek ini dipersepsi sebagai wujud zat yang menguasai dan mengetahui sepenuhnya secara utuh pergerakan dan kemunculan alam dari penyimpanan, ketersembunyian atau kegaiban berdasarkan sunnatullah yang telah ditentukanNya. Doktrin di sini adalah juga menempatkan Allah sebagai wujud zat yang mandiri, bebas dan aktif seaktif-aktifnya. Penekanan doktrin التوحيــــــ dalam kontek ini berbeda dengan atomisme Asy'ariyah, sebab dalam kontek kummunisme Muktazilah terdapat penekanan pada dua keaktifan yang berbeda, yakni keaktifan Allah sebagai pencipta di satu sisi dan keaktifan alam sebagai yang diciptakan di sisi lain.

Dalam pendekatan atomisme Asy'ariyah, dipersepsi bahwa dalam menciptakan alam, antara Tuhan dan jisim alam semesta terdapat jarak, yakni adanya $\mathbf{S}$ dan al-hayula yang masih immaterial sehingga dalam menciptakan alam dipahami bahwa Tuhan sebagai zat yang immaterial dan esa tidak bersintuhan langsung dengan alam semesta yang majemuk sehingga dengan konsep ini doktrin al-tauhid dapat terproteksi dengan baik. 
Demikian pula dalam kummunisme Muktazilah, antara Tuhan dan jisim alam semesta terdapat jarak yang lebih jauh lagi yakni $\mathbf{S}$, al-hayula dan al-kummun sehingga semakin mempertegas pemahaman bahwa dalam menciptakan alam, Tuhan sebagai zat yang immaterial dan esa tidak bersintuhan langsung dengan alam semesta yang majemuk sehingga dengan konsep ini doktrin al-tauhid semakin dapat terproteksi dengan baik.

Dengan atomisme dan kummunisme, Mutakallimin telah berhasil memberikan saluran pemikiran yang dapat memproteksi doktrin التوحيـــــ dengan tidak menggambarkan Allah yang Esa berhubungan langsung dengan alam materi yang majemuk sehingga tidak merusak konsep keesaan Allah.

Berdasarkan uraian terdahulu, dapat diketahui bahwa perbedaan pemahaman dalam masalah penciptaan alam di kalangan Asy'ariyah dan Muktazilah hanyalah karena perbedaan jalan pikiran sehingga tidak sampai melanggar hal-hal yang mendasar dalam ajaran Islam. Bahkan, perbedaan tersebut sama-sama argumentatif sebagaimana dapat dibuktikan melalui konssep sunnatullah.

Sains kontemporer sesungguhnya dapat dipakai di dalam menguatkan kebenaran jalan pikiran dua kelompok di atas. Umpamanya, teknologi kontemporer menunjukkan bahwa pikiran dan perkataan seseorangpun dapat menggerakkan detektor atau remote control. Itulah yang diterapkan pada teknologi bionik pada orang-orang yang cacat fisik. Teknologi detektor atau remote control terkait dengan energi magnetik. Magnet adalah penomena kosmologi. Penomena kosmologi seperti gravitasi dan medan magnet telah menjadi bagian dalam ilmu fisika modern. Dalam teologi Islam dipahami bahwa semua penomena itu adalah bagian dari sunnatullah. Asy'ariyah memahami sunnatullah sebagai ciptaan Allah.

Asy'ariyah berpendapat bahwa penciptaan tidak ada hentinya, hal ini relevan dengan bukti forensik yang menunjukkan bahwa selalu saja ada yang yang tidak sama dengan sebelumnya atau dengan lainnya meskipun pada jenis makhluk yang serupa yang berarti selalu terjadi ciptaan baru, tentu itu adalah sunnatullah.

Demikian pula, jika Muktazilah berpendapat bahwa penciptaan alam hanya sekali, hal ini relevan dengan doktrin penciptaan melalui kata كن. Sebagaimana telah dikemukakan di atas bahwa sains kontemporerpun telah mampu menunjukkan adanya daya atau kekuatan pada fikiran, ucapan atau perkataan. Oleh karena itu, dengan satu kata kun saja dari Allah, maka alam semesta dapat tercipta berikut dengan berbagai variasi kejadian-kejadian yang baru dan yang konsisten berdasarkan sunnatullah. Berdasarkan penjelasan di atas, dapat dikemukakan bahwa melalui jalan pikiran yang tidak sama akhirnya Asy'ariyah dan Muktazilah dapat juga bertemu pada satu kesimpulan akan ketepatan ketetapan Allah yang dikenal dengan sunnatullah. 


\section{Konsep Filsafat tentang Penciptaan Alam}

Di kalangan filosof, baik Muslim maupun non Muslim, juga terdapat pembahasan mengenai penciptaan alam yang berupa jisim-jisim. Aristoteles dan para pengikutnya, berpendapat bahwa alam, badan atau jisim terdiri dari الذات (al-zat) dan الذصورة (al-shurah).

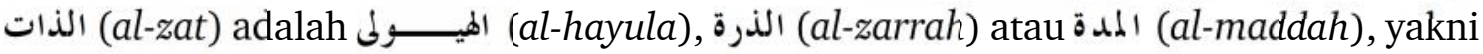
atom-atom atau molekul-molekul. Sedangkan الصورة الذرة (al-shurah) adalah gambar atau sifat. Baik al-hayula maupun al-maddah adalah tidak mempunyai bentuk dan tidak dapat dibagi sehingga tidak dapat diamati jika antara keduanya terpisah secara sendiri-sendiri. Apabila keduanya dikombinasikan, maka jadilah jisim karena jisim adalah perpaduan. Setelah menjadi jisimlah baru dapat dibagi-bagi. Pemikiran ini dilatarbelakangi oleh pemahaman bahwa alam ini diciptakan dari bahan baku yang sudah ada, itulah الذات (al-zat) dan الصورة (al-shurah). Dengan demikian, alam ini terbentuk ketika الذات (al) bersatu dengan الصورة (al-shurah).

Kalau perbincangan mengenai penciptaan alam di kalangan Mutakallimin di atas melahirkan dua teori, yakni atomisme di kalangan Asy'ariyah dan kummunisme di kalangan Muktazilah, maka perbincangan mengenai penciptaan alam di kalangan filosof juga melahirkan teori yang pada umumnya disebutsebagai emanasi. Di kalangan filosof muslim dikenal dengan teori الفيــــ (al-faid). Konon teori ini berasal dari filsafat emanasi Plotinus. Dalam

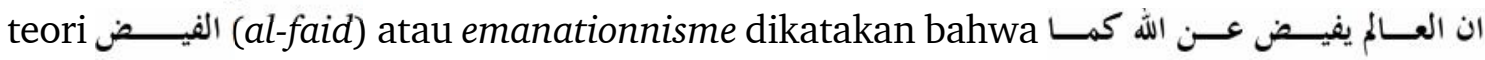

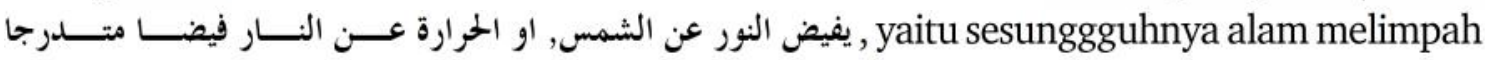
dari Allah secara berangsur-angsur sebagaimana cahaya melimpah dari matahari atau panas dari api. ${ }^{18}$

Filosof muslim, al-Farabi dan Ibn Sina kemudian menggunakan teori emanasi di atas untuk membuat formulasi mengenai penciptaan alam sehubungan dengan persoalan rumit terkait dengan penjelasan tentang: Bagaimanakah Allah SWT. yang bersifat immaterial menciptakan alam semesta yang di dalamnya terdapat sesuatu yang bersifat immateri dan juga materi, namun tidak merusak keesaanNya.

Sebagaimana telah disebut di atas, dalam filsafat Islam formulasi tersebut dikenal dengan teori الفيـــ (emanasi), yang berarti pelimpahan. Teori ini populer juga dengan nama teori akal sepuluh, yakni Allah menciptakan alam ini melalui akal-akal. Oleh karena jumlahnya sepuluh, maka dipahami juga oleh sebagian kalangan bahwa ada kaitannya dengan sepuluh Malaikat sebagaimana yang wajib diketahui oleh setiap mukmin.

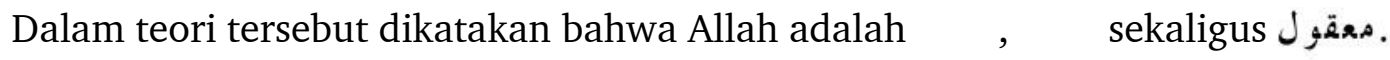
Sebagai علأل (Yang berfikir), Allah yang merupakan الوجود الاول (wujud pertama) berpikir

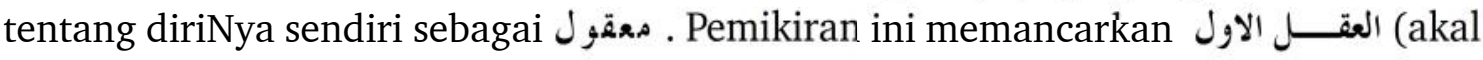
pertama) yang merupakan الوجــود الثــاني (wujud kedua). Akal pertama yang merupakan

\footnotetext{
${ }^{18}$ Jamil Shaliba, al-Mu'jam al-Falsafi, Jilid II (Lebanon: Dâr al-Kitâb, 1979), h. 173.
} 
wujud kedua ini mempunyai dua sifat, yakni 1). Dilihat berdasarkan pemunculannya sebagai pancaran dari Tuhan, maka ia adalah وجب الوجود 2). Dilihat dari hakekat dirinya, maka ia adalah مككن الوجود. Sehubungan dengan ini, maka akal pertama dan seterusnya sampai akal kesepuluh mempunyai tiga objek pemikiran, yaitu: 1). Tuhan; 2). Dirinya

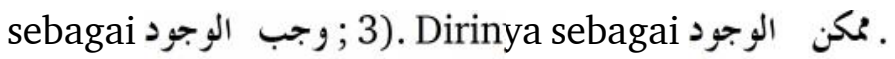

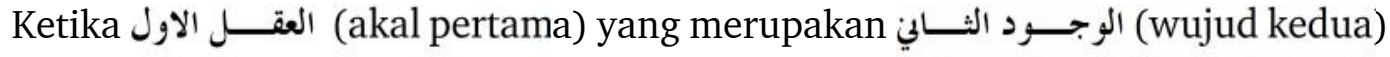

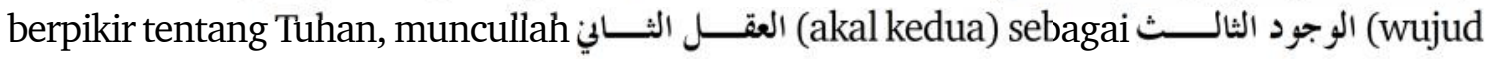
ketiga). Ketika memikirkan dirinya sebagai وجب الوجود الوجئ muncullah jiwa langit pertama. Ketika memikirkan dirinya sebagai منكن الوجود muncullah jisim langit pertama. Demikian seterusnya sampai akal kesepuluh, sebagaimana dijelaskan pada tabel berikut: ${ }^{19}$

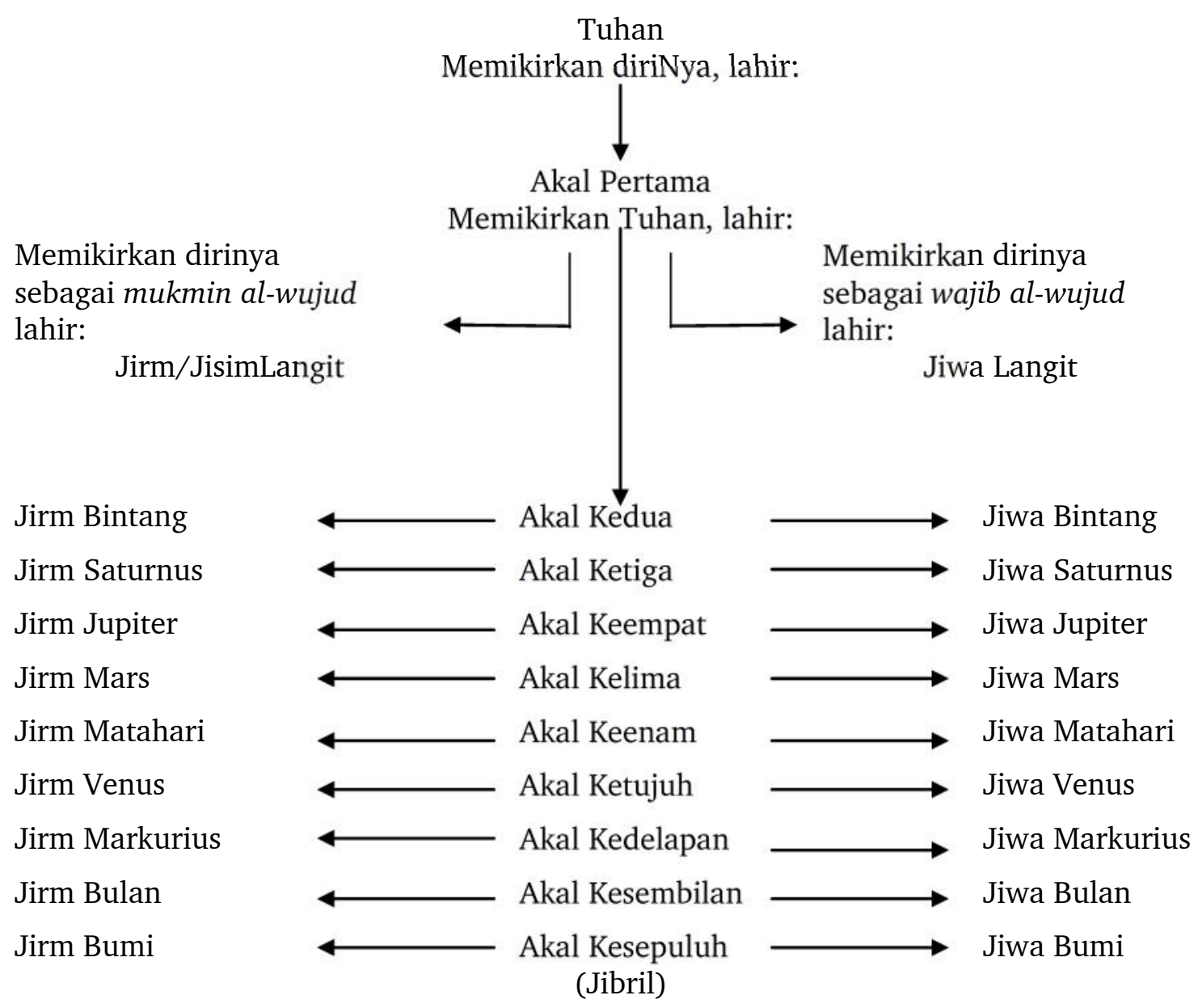

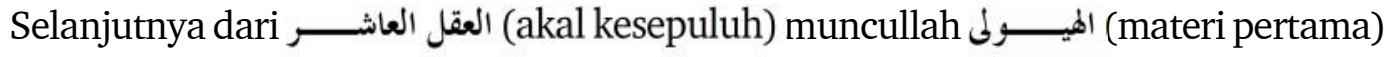
yang mengandung unsur api, udara, tanah, dan air. Berikutnya ada 'aradh atau shurah sebagai sifat yang datang kemudian. Jika الهيـــــ (materi pertama) berpadu dengan 'aradh atau shurah (sifat atau gambar) maka terciptalah جسم (jisim).

${ }^{19}$ PT. Ichtiar Baru Van Hoeve, Ensiklopedi Islam, Jilid II (Jakarta: PT. Ichtiar Baru Van Hoeve, 1997), h. 325. 
Dengan tiga objek pemikiran akal-akal dalam teori الفيــــ (emanasi), para filosof muslim di atas mampu menjelaskan bagaimana Allah sebagai sesuatu yang immaterial menciptakan alam semesta yang terdiri dari immateri, yaitu الروح atau النفـس atau atau ruh) dan materi, yaitu الجرم الجرم atau (materi).

Tori di atas dapat menunjukkan betapa filosof berusaha menemukan saluran pemikiran yang dapat mengantarkan konsep penciptaan alam tidak berbenturan dengan doktrin tauhid yang mengajarkan keesaan Allah.

Dalam ajaran tauhid, Allah disebut Esa sehingga dalam penciptaan alam semesta sebagai sesuatu yang جزئيــــ atau majemuk/banyak dan terperinci, Allah tidak boleh sampai bersintuhan dengan alam karena dapat merusak konsep ke-EsaanNya. Dalam kaitan inilah filosof memberi pemahaman bahwa dalam menciptakan alam, Allah tidak bersintuhan langsung dengan alam yang majemuk tersebut karena ada akal-akal atau intelek. Melalui teori inilah para filosof berperan di dalam menjaga konsep التوحيــ. Namun, teori pelimpahan akal-akal atau intelek ini bukan sama sekali lepas dari kritik sebab sebagai sesuatu yang langsung melimpah dari Tuhan sebagai zat yang qadim atau azali keberadaan akal-akal atau intelek tersbut rentan untuk dapat ditarik kepada peng-qadim-an sesuatu selain Allah, yaitu intelek atau akal itu sendiri. Hal ini dimungkinkan karena secara konsepsional di dalam al-faidh itu tidak ditemukan rumusan akan adanya saat tatkala apapun tidak ada kecuali Allah. Dalam kontek inilah juga tampaknya sisi lemah teori الفيــــ (emanasi) sehingga harus masih disempurnakan melalui doktrin kun fayakun sebagaimana yang dikemukakan di dalam al-Qur'an.

\section{Konsep al-Qur'an tentang Penciptaan Alam}

Al-Qur'an tidak hanya menginformasikan penciptaan alam, tetapi juga menginformasikan prilaku alam. Informasi penciptaan alam ditemukan pada ayat-ayat dengan lafaz Sن (Q.S.al-Baqarah/2: 117; Âli 'Imrân/3: 47-59; al-An'âm/6: 73; al-Nahl/6: 40; Q.S. Maryam/19: 35; Q.S. Yasin/36: 82; Q.S. Gafir/40: 68). dapat dikemukakan bahwa penciptaan alam dalam al-Qur'an diisyaratkan terjadi melalui

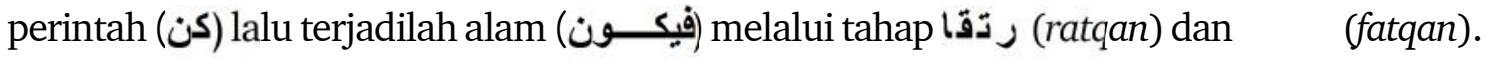

Dalam menciptakan alam, Allah hanya menyebut s maka terciptalah alam semesta. Penciptaan alam versi al-Qur'an ini merupakan pedoman yang paling praktis di antara sekian banyak teori penciptaan alam yang telah dikemukakan terdahulu. Informasinya sekaligus dapat menyahuti dan melengkapi semua teori yang telah dikemukakan. Di antara informasi al-Qur'an yang dapat dipandang sebagai melengkapi teori sains, teologi dan filsafat adalah kata فيكون فئنyang terjadi sebelum munculnya perilaku alam, seperti رتقا (padu)

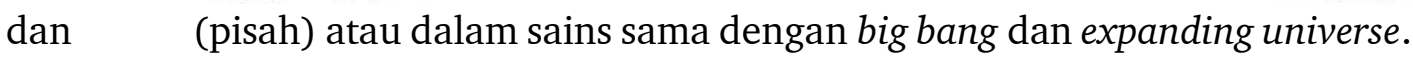

${ }^{20}$ Muhammad Fuad Abd al-Baqi, al-Mu'jam al-Mufahras li Alfaz al-Qur'ân al-Karîm (Kairo:

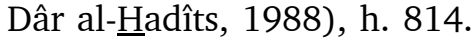


Sesuai dengan penjelasan di atas, selanjutnya dapat dikemukakan sejumlah ayat yang menginformasikan perilaku alam yang lazim disebut sebagai ayat-ayat kauniyah. Di antara ayat-ayat dimaksud adalah sebagai berikut:

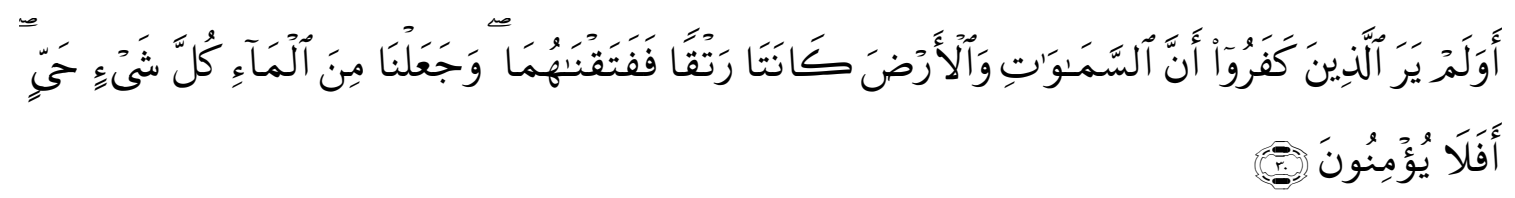

Dan Apakah orang-orangyang kafir tidak mengetahui bahwasanya langit dan bumi itu keduanya dahulu adalah suatu yang padu, kemudian Kami pisahkan antara keduanya. Dan dari air Kami jadikan segala sesuatu yang hidup. Maka Mengapakah mereka tiada juga beriman? (Q.S. al-Anbiyâ'/21: 30)

Ayat di atas mengandung pesan adanya dua pase pada alam yang diistilahkan dengan

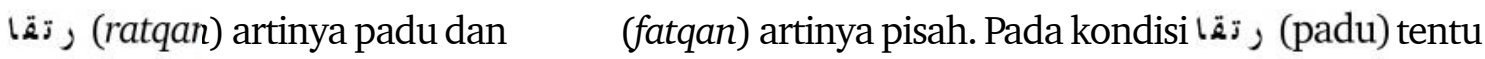
alam dalam keadaan merapat, bertemu dan menyatu. Sedangkan pada kondisi L_ ف̇ípisah), alam yang tadinya padu menjadi pecah dan terbelah.

Dalam ayat lain Allah berfirman

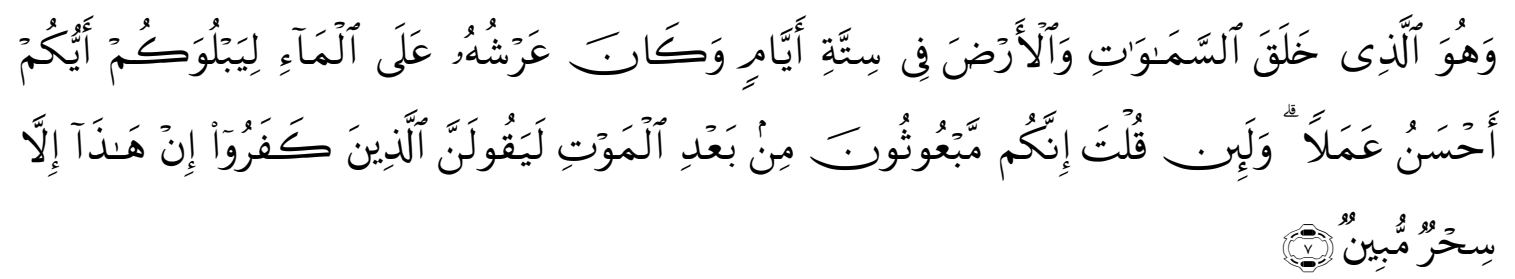

Dan Dia-lah yang menciptakan langit dan bumi dalam enam masa, dan adalah singgasanaNya (sebelum itu) di atas air, agar Dia menguji siapakah di antara kamuyang lebih baik amalnya, dan jika kamu berkata (kepada penduduk Mekah): "Sesungguhnya kamu akan dibangkitkan sesudah mati", niscaya orang-orang yang kafir itu akan berkata: "Ini tidak lain hanyalah sihir yang nyata" (Q.S. Hud/11: 7).

Informasi yang terdapat pada ayat-ayat yang dikemukakan di atas, mekankan pada adanya tahapan-tahapan di dalam penciptaan alam yang hal ini tidak dapat dijangkau oleh sains, teologi dan filsafat. Tahapan-tahapan ini menunjukkan kesempurnaan kekuasaan Allah di dalam menciptakan langit dan bumi. Allah menyempurnakan bagi masing-masing langit hal-hal yang menjadikan mereka siap melaksanakannya. Dia menghiasi langit dengan bintang-bintang dan planet-planet, baik yang tetap maupun yang bergerak.

Sedangkan ayat-ayat selanjutnya di bawah ini menekankan pada asfek pengaturan alam seperti sistem kesimbangan, yang dapat mengantarkan manusia kepada pengakuan akan kekuasaan Allah.

Sistem keseimbangan sangat penting dalam semua hal, fisik maupun non fisik. Allah menciptakan tujuh lapis langit dan tujuh lapis bumi sesuai firmanNya: الله الــــى 
خلق السموات ومــن الارض مثلـــهن (Q.S. al-Thalaq/65: 12) dengan tidak saling berbenturan. Kesinambungan Langit dan Bumi yang berlapis-lapis itu tak dapat tidak karena keseimbangan. Hal ini dinyatakan dalam firmanNya:

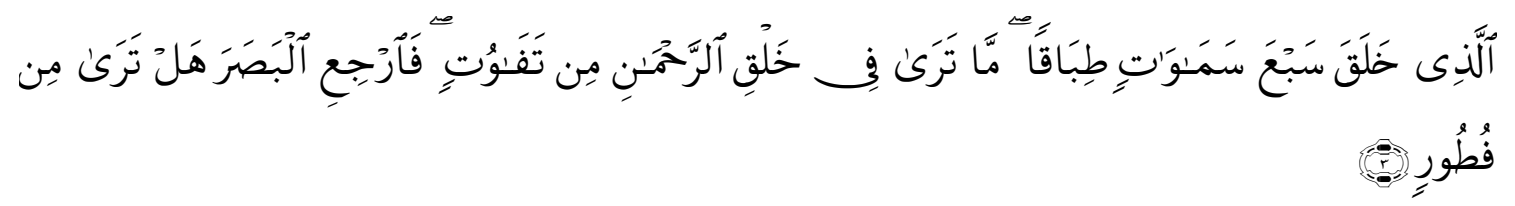

Yang telah menciptakan tujuh langit berlapis-lapis. Kamu sekali-kali tidak melihat pada ciptaan Tuhan yang Maha Pemurah sesuatu yang tidak seimbang. Maka lihatlah berulangulang, Adakah kamu lihat sesuatu yang tidak seimbang? (Q.S. al-Mulk/67: 3).

Sesuai dengan kandungan ayat-ayat tersebut di atas, berdasarkan sains juga dapat diketahui bahwa dengan sistem keseimbanganlah, seperti orbit dan rotasi pada planet di tatasurya, segala sesuatunya di alam ini dapat bertahan. Hal ini juga ditegaskan dalam ayat al-Qur'an:

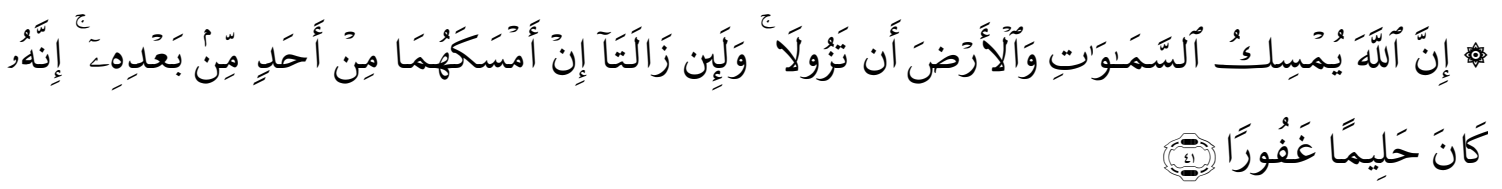

Sesungguhnya Allah menahan langit dan bumi supaya jangan lenyap; dan sungguh jika keduanya akan lenyap tidak ada seorangpun yang dapat menahan keduanya selain Allah. Sesungguhnya Dia adalah Maha Penyantun lagi Maha Pengampun (Q.S. Fathir/35: 41).

Ayat di atas menunjukkan bahwa kesinambungan kehidupan di alam dapat bertahan sepanjang Allah menjaganya agar tidak lenyap. Namun, dalam berbagai ayat lain diinformasikan akan adanya kehidupan akhirat dengan berbagai ketentuannya.

Bertitiktolak dari uraian di atas, dapat dikatakan bahwa dalam masalah penciptaan alam, ayat-ayat al-Qur'an melengkapi teori yang dikemukakan oleh para ilmuan, teolog dan filosof melalui informasi yang berhubungan dengan masa serta ketentuan-ketentuan mengenai penghuninya dan sistem yang berlaku di dalamnya. Demikian pula melalui doktrin kun fayakun dalam al-Qur'an dapat menyempurnakan setiap sisi lemah dari semua teori tersebut.

\section{Sinergitas Teori Penciptaan Alam}

Dapat diakui bahwa masalah masa penciptaan alam adalah merupakan sesuatu yang sulit dijangkau secara tuntas oleh sains maupun filsafat yang hanya berpijak pada akal manusia. Demikian pula dengan masalah yang berhubungan dengan ke-qadim-an atau ke-azali-an Allah yang hanya dapat dipahami melalui informasi wahyu bahwa ada saat tatkala apapun tidak ada kecuali Allah, ketika Allah dalam kesendirianNya sebagaimana diisyaratkan dalam lafaz قل هو الله احسـد : اللّ احسـ yang terdapat pada ayat-Ikhlâsh/ 
112: 1). Untuk memahami informasi wahyu semacam ini, tampaknya pendekatan teologi lebih tepat digunakan untuk dijadikan pilihan dibanding sains maupun filsafat.

Sejak awal terbentuknya sejarah peradaban sampai sekarang, teologi telah menjadi bagian penting di dalam kehidupan manusia. Mulai dari masalah bercocok tanam pada masyarakat primitif sampai pada penentuan memilih perguruan tinggi di kalangan mahasiswa pada masyarakat modern tidak bisa lepas dari teologi. ${ }^{21}$ Respon teologis pertama manusia terhadap lingkungannya muncul dalam bentuk supernaturallisme. Dalam kontek inilah lahirnya berbagai paham seperti dinamisme, animisme, politisme, henoteisme, dan monoteisme.

Agama-agama besar menempatkan teologi pada posisi paling sentral dalam ajarannya. Oleh karena itu sangat beralasan jika umat beragama banyak mengaitkan berbagai persoalan dalam kehidupannya dengan pendekatan teologis. Teologi secara normatif diajarkan di dalam kitab suci masing-masing agama. Setiap pemeluk agama yang taat sangat berhatihati di dalam masalah ini sehingga berbagai hal yang terjadi dalam kehidupan selalu dilihat dari kacamata teologi. Namun perlu dicermati bahwa dominasi teologi dapat melahirkan teocentrisme. Segala sesuatunya diukur dari sudut ketuhanan. Pertimbangan dan argumentasi sains, teknologi dan filsafat menjadi terabaikan. Dalam konteks ini maka ketaatan seseorang terhadap agamanya dipandang semata-mata terkait dengan konsistensinya dalam teologi. Dalam pada itu, tidak jarang di kalangan banyak agamawan konsep-konsep teologi dipahami sebagai sesuatu yang sudah final sehingga resisten terhadap perubahan.

Secara umum di kalangan umat beragama terdapat dua kelompok teologis yang berseberangan. Pertama, kelompok tradisional, konservatif, ortodoks, irrasional dan tekstual. Dalam kelompok inilah berkembangnya teocentrisme. Kedua, kelompok modernis, rasional dan kontekstual. Dalam kelompok ini berkembang anthropocentrisme. ${ }^{22}$ Kedua kelompok ini kontradiktif di dalam menyikapi berbagai hal termasuk dalam masalah relasi agama, sains dan teknologi. Jika kelompok pertama melahirkan disharmoni. Kelompok kedua melahirkan harmoni antara agama, sains dan teknologi.

Berdasarkan argumen teologis, agamawan menyimpulkan bahwa dunia lahir pada jam 9 pagi hari Minggu 23 Oktober 4004 SM. Pendapat ini berbeda dengan fakta ilmiah yang pernah dikemukakan oleh seorang ilmuan, Wycliffe, yang membuktikan berdasarkan fosil dan geologi, bumi paling sedikit telah berusia beberapa ratus ribu tahun. Para teolog memandang pendapat ini suatu penghinaan terhadap agama. Karena tidak dapat menerima penghinaan ini mereka menggali kembali tulang belulang Wycliffe untuk dipatah-patahkan

${ }^{21}$ Ilhamuddin, "Persepsi Calon Mahasiswa Baru Terhadap IAIN Sumatera Utara," dalam Intizar Jurnal Kajian agama Islam dan Masyarakat2006, h. 43-56; Ilhamuddin, "Pengaruh Teologi Terhadap Mahasiswa Fakultas Dakwah IAIN Sumatera Utara-Medan," dalam Majalah Media PendidikanVol. XXIII, No.3, September-Desember, 2006, h. 365-380.

${ }^{22}$ Ilhamuddin, "Anthropocentrisme dan Theocentrisme," dalam Jurnal Ushuluddin, JanuariPebruari-Maret, 1994, h. 54. 
dan dibuang ke laut. Dengan tindakan tersebut mereka memandang penolakan terhadap agama menjadi hilang. ${ }^{23}$

Resistensi para teolog yang demikian tinggi dan sengit menentang para ilmuan, seperti Bacon, Wycliffe, Bruno, Galileo, dan 10.000-an pemikir lainnya tampaknya berkaitan dengan berbagai sebab. Di antaranya adalah: (1) Dominasi pemahaman tekstual dalam agama; (2) Adanya kepentingan kuat untuk memaksakan dogma-dogma teologi; (3) Kesangsian bahwa jika terjadi penolakan atas satu aturan saja, apakah melalui sains atau yang lainnya dapat menyebabkan keruntuhan dan ketidakukuhan seluruh tatanan social; (4). Oleh karena itu sains dan pemikiran bebas adalah ancaman dan harus dilarang.

Dalam kaitan itulah teolog menghukum Galileo. Hukuman terhadap Galileo meskipun sama sekali bukan merupakan contoh yang paling ekstrim dalam catatan sejarah, tetapi memiliki arti khusus karena inilah larangan efektif pertama dari agamawan terhadap pendapat ilmiah.

Bernard Shaw mengemukakan pengamatannya, bahwa dihukumnya Galileo bukanlah karena faktor kontradiksi antara teori "bumi bergerak mengelilingi matahari" (helio centrisme) dan "bumi pusat stasioner yang dikelilingi matahari" (geocentrisme). Persoalannya bukan itu. Sesungguhnya, teori ini adalah fakta fisik tanpa dimensi moral yang berarti. Karena itu tidak memiliki efek terhadap teologi. Namun dalam keyakinan para teolog, karena agama menjadi tempat bergantung peradaban dunia, maka pergeseran pemahaman (geocentrisme ke heliocentrisme) yang diakibatkan oleh sains dapat berakibat buruk terhadap agama. ${ }^{24}$

Kaum agamawan Eropa selama 1000 tahun mempertahankan doktrin bahwa tidak ada kehidupan manusia di sisi bumi yang lain. Meskipun secara ilmiah dapat dibuktikan bahwa bumi memiliki sisi yang berlawanan. Pada abad ke-6, Procopius dari Gaza membawa senjata teologis untuk mendukung keyakinan itu. Dia mengatakan tidak mungkin ada sisi yang berlawanan. Karena dengan demikian Kristus harus pergi ke sana dan menderita untuk yang kedua kalinya. Di samping itu, harus ada duplikat surga, Adam, iblis, dan banjir besar. Oleh karena itu pendapat tentang bulatnya bumi menurut agamawan Eropa adalah sesuatu yang salah. Ini merupakan sebagian dari penyebab terjadinya disharmoni relasi agama, sains dan teknologi di luar Islam.

Bukti lain dari terjadinya disharmoni relasi itu dapat dilihat dari berbagai pendapat agamawan lainnya terhadap berbagai penomena alam dan kehidupan sosial. Seperti Santa Paul dan Origen. Menurut Santa Paul, penyakit adalah akibat pekerjaan setan yang sangat jahat. Menurut Origen; setanlah yang menyebabkan kelaparan, ketidakberdayaan, pencemaran udara dan wabah. Setan melayang-layang bersembunyi di balik awan. Kemudian turun ke bumi karena mencium darah dan dupa yang ditawarkan oleh penyembah berhala.

${ }^{23}$ Pervez Hoodbhoy, Ikhtiar Menegakkan Rasionalitas: antara Sains dan Ortodoksi Islam, terj. Sari Meutia (Bandung: Mizan, 1996), h. 56-59.

${ }^{24}$ Ibid. 
Augustine, juga mengemukakan pendapatnya bahwa semua penyakit berasal dari setan. Setan menyiksa orang-orang yang baru dibaptis. Bahkan bayi-bayi tak berdosa yang baru lahir sekalipun.Ruh setan dan kejahatanlah yang menyebabkan penyakit. Penyembuhannya dilakukan dengan mengusir setan itu melalui alat-alat seperti benda-benda sakral. Banyak sumbangan mengalir ke berbagai rumah ibadah yang terkenal memiliki benda-benda sakral yang dipandang dapat menyembuhkan penyakit. Dalam konteks ini rumah ibadah bukan hanya pelindung jiwa tetapi juga pelindung fisik. Dalam kaitan inilah terjadinya resistensi yang sangat kuat terhadap ilmu kedokteran. Pemahaman agama seperti tersebut selanjutnya melahirkan takhayul. Sedangkan fakta ilmiah kemudian melahirkan teknologi kesehatan. ${ }^{25}$

Penentangan serius dalam perkembangan kedokteran ilmiah adalah penolakan terhadap teknologi pembedahan mayat. St Augustine menyebut ahli anatomi sebagai 'tukang jagal' dan mencela praktik ini dengan tegas. Dalam pandangan agamawan pada umumnya pemotongan mayat akan menimbulkan kengerian yang tak terbayangkan pada hari kiamat. Di samping itu, menurut mereka 'teologi membenci pertumpahan darah. ${ }^{26}$

Argumen di atas kontradiktif dengan fakta bahwa agamawan pernah membakar ribuan pendosa dan ahli-ahli sihir yang dicurigai. Fakta tersebut menunjukkan bahwa para teolog tidak terlalu membenci penumpahan darah bila itu menyangkut kepentingan mereka sendiri.

Agamawan juga menganggap geologi sebagai alat yang sangat subversive dalam pelayanan setan. Bukan saja bukti geologis menolak penegasan Uskup Agung Ussher mengenai usia bumi, tetapi juga menunjukkan kemustahilan penciptaan semesta dalam enam hari. Kaum ortodoks menyatakan bahwa geologi 'bukan ilmu yang sah menurut hukum'. Geologi adalah 'seni yang hitam', artileri neraka' dan menyatakan pelakunya sebagai 'kafir yang menyebabkan keraguan terhadap naskah suci'. Atas dasar simpatinya terhadap pernyataan ini, Paus Pius IX melarang kongres ilmiah Itali untuk berkumpul di Bologna pada tahun $1650 .{ }^{27}$

Selama abad pertengahan, doktrin tentang asal usul badai telah diterima secara umum. Doktrin tersebut mendapat dukungan dari para penguasa dan agamawan seperti St Augustine. Badai menurut mereka adalah perbuatan setan. Untuk melawan 'kekuatan udara' yang luar biasa ini dilakukan segala macam ibadah pengusiran setan. Yang paling sering dipakai adalah ibadah dari Paus Gregory XIII. Pada mulanya, setan diusir dengan berbagai nyanyian dan membunyikan lonceng selama badai. Sementara pada abad k15 berkembang keyakinan tragis bahwa wanita-wanita tertentu dapat mendatangkan bantuan dari neraka untuk menyebabkan angin puyuh, hujan es, banjir dan sejenisnya. Pada 7 Desember 1484, Paus Innocent VIII mengeluarkan keputusan resmi yang diilhami

\footnotetext{
${ }^{25}$ Ibid.

${ }^{26} \mathrm{Ibid}$.

${ }^{27}$ Ibid.
} 
oleh perintah wahyu 'kamu tidak boleh menderita dengan membiarkan tukang sihir hidup'. Dia segera mendesak agamawan untuk melacak para tukang sihir dan ahli sulap yang menyebabkan cuaca buruk. Maka ribuan wanita mengalami siksaaan yang kejam di hadapan orang-orang terdekat dan tersayang mereka. Mereka berharap untuk mati secepatnya agar terbebas dari penderitaan..$^{28}$

Halilintar, menurut dogma agama, adalah konsekuensi dari lima dosa, yaitu (a) tidak bermalu, (b) tidak percaya, (c) menolak untuk merawat rumah ibadah, (d) curang dalam pembayaran pajak kepada rumah ibadah, dan (e) menekan yang lemah. Paus menyebut hukuman Tuhan ini dengan 'jari-jari Tuhan'. Kemudian pada tahun 1752, ketika sedang terjadi badai elektrik, Benyamin Franklin menerbangkan layang-layangnya. Dalam eksperimennya itu ia menemukan bahwa petir hanyalah gejala elektrisitas biasa. Penemuan tersebut segera diikuti dengan pembuatan penangkal petir. Pelindung yang aman bahkan dari badai paling mengerikan sekalipun. Pada awalnya agamawan menolak untuk mengakui keberadaan teknologi penangkal petir ini. Tetapi kemudian, begitu keampuhan dari konduktor petir ini diakui secara luas dan semakin banyak dipasang kaum ortodoks menentangnya dengan keras. Sejalan dengan itu gempa bumi di Massachusset pada tahun 1755 disikapi sebagai akibat luasnya pemakaian alat penangkal petir Franklin di Boston. Pertentangan ini tadinya akan berlangsung lama. Namun ternyata rumah-rumah ibadah tanpa penangkal petir seringkali hancur disambar petir.

Ketika Immanuel Kant memperkenalkan teori tentang nebula dan bintang-bintang, agamawan menentangnya karena mereka tidak melihat adanya rujukan mengenai hal itu di dalam kitab suci. Oleh karena itu menurut mereka nebula tidak ada. Para pendukung teori nebula ini baru bisa lega ketika teleskop dapat dibuat lebih baik sehingga menunjukkan bahwa beberapa pola materi nebula ternyata dapat dipisahkan menjadi bintang-bintang. Tetapi dengan berlalunya waktu masuklah era penemuan spektroskop dan analisis spectrum. Cahaya dari nebula ternyata berasal dari materi gas antar bintang. Dengan demikian agamawan ortodoks akhirnya mengalah. ${ }^{29}$

Daftar kekejaman agamawan dan penguasa Eropa abad pertengahan dalam menentang sains dan teknologi jauh lebih panjang daripada uraian di atas. Konflik antara sains dan ortodoksi masih terjadi sampai masa kepresidenan Ronald Reagan. sekitar 1980-an dalam gerakan Kreasionis di Amerika Serikat. Gerakan ini mendapat banyak sambutan dan mendapat pendukung di banyak negara bagian. Ajaran Kreasionis memiliki keyakinan utama bahwa semua kehidupan di alam semesta diciptakan sekitar 6000 tahun lalu, selama 7 hari, persis seperti yang digambarkan dalam bab-bab pertama Genesis. Jadi, Banjir Besar dianggap sebagai fakta sejarah. Tidak hanya sebagai kiasan. Ajaran Kreasionis menyerang semua bidang astronomi dan geologi yang menyatakan usia bumi lebih dari 10.000 tahun. Dalam

${ }^{28}$ Ibid.

${ }^{29} \mathrm{Ibid}$. 
kaitan ini, pendataan karbon radioaktif ditolak. Demikian pula dengan teori Darwin mengenai evolusi. Teori ini menimbulkan kemarahan besar. Hakim Braswell Deen, seorang kreasionis dan hakim dari Georgia State Court Of Appeals menulis bahwa 'mitologi monyet dari Darwin' menyebabkan 'kebebasan, perzinaan, perkembangan kejahatan. ${ }^{30}$ Walaupun terjadi kebangkitan ortodoksi di Barat, perang terhadap kebangkitan sains tidak banyak berarti. Mereka tidak berhasil memaksa sekolah-sekolah agama menetapkan waktu penciptaan yang sama menurut sains dan menurut Bibel. Dengan berakhirnya kepresidenan Reagan, ajaran kreasionispun mengalami kemunduran. Di samping itu, dunia modern tidak mau membiarkan agamawan melupakan kekejaman masa lalunya. Simbol dari semua ini adalah penyiksaan Galileo dan penolakan keras atas pandangan ilmiahnya.

\section{Penutup}

Bertitiktolak dari uraian di atas dapat ditarik kesimpulan bahwa ada empat pendekatan yang saling melengkapi di dalam memberikan penjelasan mengenai persoalan penciptaan alam, yakni sains, teologi, filsafat dan al-Qur'an. Bagi saintis persoalan penciptaan alam adalah murni kepentingan sains sehingga sains tidak sampai pada wilayah teologis maupun metafisis-filosofis yang berupaya mencari hubungannya dengan Tuhan.

Berbeda dengan saintis, bagi teolog muslim persoalan ini dipandang berhubungan dengan doktrin التوحيـــــ sehingga berbagai macam pemikiran yang muncul di sekitar masalah tersebut tidak dapat dibiarkan berkembang tanpa arah yang sesuai dengan doktrin لتوحيـــــــ tersebut karena dapat merusak aqidah umat Islam. Meskipun demikian, pada dasarnya penemuan sains tentang konsep alam semesta tidaklah kontradiktif dengan apa yang dikemukakan dalam al-Qur'an, hanya saja menyisakan sisi gelap yang membutuhkan penjelasan lanjutan.

Secara umum al-Qur'an memberi kategori alam "gaib” sebagai jawaban terhadap misteri dimaksud, yaitu sesuatu yang wajib diimani sebagai bagian dari ketaqwaan terhadap Allah karena dalam al-Qur'an orang bertakwa yang kemudian diurai secara teologis dan filosofis oleh para Mutakallimin dan Filosof muslim. Mutakallimin maupun Filosof telah berhasil mengemukakan tiga macam teori, yaitu atomisme, kummunisme dan emanasi. Ketiga teori ini mempunyai kedekatan terutama dalam masalah tujuan, yaitu memproteksi

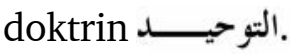

Kedekatan yang terdapat pada ketiga teori di atas dapat dilihat dari adanya materi

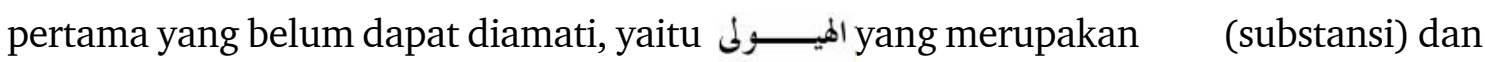

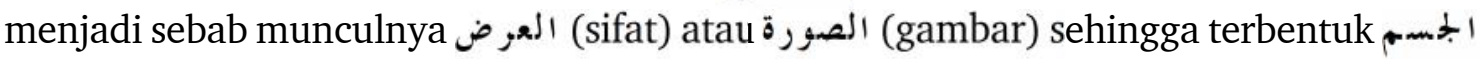
(al-jism) atau الجحرم (jirm), yaitu badan sebagai sesuatu yang nyata dan dapat diamati.

${ }^{30}$ M.C. La Polette, Cretionisme, Science, and the Law- the Arkansas Case (Cambridge, Mass, MIT Press, 1983). 


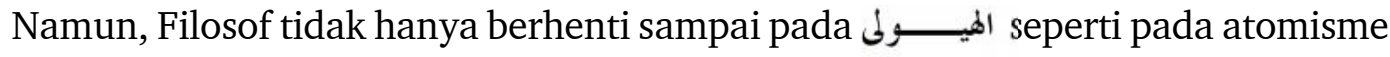

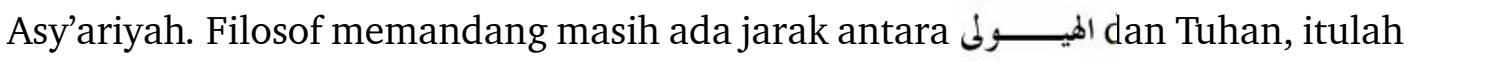
atau intelek yang adalah juga immaterial. Namun, filosof juga kemudian berhenti pada akal atau intelek sehingga rumusan filsafat al-faidh mereka juga tetap tidak bebas kritik karena teori pelimpahan intelek yang langsung dari Tuhan rentan dapat ditarik kepada peng-qadim-an sesuatu selain Tuhan seperti intelek itu sendiri sehingga dapat berbenturan dengan doktrin tauhid. Dalam kontek ini ada nilai plus dari kummunisme Muktazilah yang menjadikan pase kummun (tersembunyi) itu dapat dikembangkan sampai pada adanya saat tatkala apapun tidak ada kecuali Allah yang dalam konsep metafisika disebut sebagai realitas absolut atau Hahut.

Dengan demikian, dapat dikatakan bahwa doktrin kun fayakun yang terdapat dalam al-Qur'an merupakan pamungkas dari berbagai pendekatan dan teori penciptaan alam yang dikembangkan dalam sains, teologi dan filsafat. Sinergitas dari semua pendekatan dan teori tersebut berpotensi kuat dapat membantu bagi pemantapan keimanan terutama di kalangan intelektual. Dengan konsep sinergitas sesuangguhnya tidak mesti ada risistensi dan dikhotomi antara sains, teknologi, teologi dan filsafat dengan agama.

\section{Pustaka Acuan}

Al-Qur'an al-Karim

Kitab Perjanjian Lama

Al-Baqillani. Kitâb Tamhid al-Awâ'il wa Talkhis al-Dalâ'il. Beirut: Muassasat al-Kutub alTsaqafiyyah, Beirut, 1987.

White, Andrew Dickson. a History of the Warfare of Science With Theology. Gloucester, Mass, 1896.

Glasse, Cyril. Ensiklopedi Islam (Ringkas). Jakarta: RajaGrafindo Persada, 1996.

Ilhamuddin, "Anthropocentrisme dan Theocentrisme," dalam Jurnal Ushuluddin, JanuariPebruari-Maret, 1994,

Shaliba, Jamil. al-Mu'jam al-Falsafi, Jilid II. Lebanon: Dâr al-Kitâb, 1979.

Q. Shaleh, et al. Asbabun Nuzul, Bandung: Diponegoro, 1992.

bin Nabi, Malik. Fenomena al-Qur'an, terj. Saleh Mahfoed. Bandung: Al-Ma'arif, Bandung, 1983.

al-Baqi, Muhammad Fuad Abd. al-Mu'jam al-Mufahras li Alfazh al-Qur'ân al-Karîm. Kairo: Dâr al-Hadîts, 1988.

Dawud, Muhammad Isa. Dialog dengan Jin Muslim Pengalaman Spritual. Bandung: Pustaka Hidayah, 2011.

Polette, M.C. La. Cretionisme, Science, and the Law-the Arkansas Case. Cambridge: Mass, MIT Press, 1983. 
MIQOT Vol. XXXVIII No. 2 Juli-Desember 2014

Hoodbhoy, Pervez. Ikhtiar Menegakkan Rasionalitas: antara Sains dan Ortodoksi Islam, terj. Sari Meutia. Bandung: Mizan, 1996.

Ichtiar Baru Van Hoeve. Ensiklopedi Islam, Jilid II. Jakarta: Ichtiar Baru Van Hoeve 1997.

Hitti, Philip K. History of the Arabs, terj. R. Cecep Lukman Yasin dan Dedi Slamet Riyadi: Jakarta: Serambi Ilmu Semesta, 2006.

Pusat Bahasa Departemen Pendidikan Nasional. Kamus Besar Bahasa Indonesia. Jakarta: Balai Pustaka, 2001.

al-Attas, Syed Muhammad Naquib. a Commentary on Hujjat al-Shiddiq of Nur al-Din alRaniry. Kuala Lumpur: Ministry of Culture, 1986.

al-Attas, Syed Muhammad Naquib. Islam and the Philosophy of Science. Kuala Lumpur: ISTAC, 1989.

al-Attas, Syed Muhammad Naquib. Islam and Secularism. Kuala Lumpur: ISTAC, 1978.

al-Attas, Syed Muhammad Naquib. Islam and the Philosophy of the Future. Mansell Publishing Limited, London \& New York, 1985.

al-Attas, Syed Muhammad Naquib. Islam dan Filsafat Pengetahuan, terj. Saiful Muzani, Mizan, Bandung, 1995.

al-Attas, Syed Muhammad Naquib. Islam Faham Agama dan Akhlaq, ISTAC, Kuala Lumpur, 1977.

al-Attas, Syed Muhammad Naquib. Islam, Secularism and the Philosophy of the Future. London \& New York: Mansell Publishing Limited, 1985.

al-Attas, Syed Muhammad Naquib. Islam: Faham Agama dan Asas Akhlaq. Kuala Lumpur: ABIM, 1977.

al-Attas, Syed Muhammad Naquib. Islamic Philosophy: An Introduction, http:// www.muslimphilosophy.com/-journal/is-01/attas 1.htm.

al-Attas, Syed Muhammad Naquib. Positive Aspect of Tashawwuf: Preliminary Thoughts on an Islamic Philosophy of Science, Islamic Academy of Science, 1981.

al-Attas, Syed Muhammad Naquib. Prolegomena to the Metaphysics of Islam: an Exposition of the Fundamental Elements of the Worldview of Islam. Kuala Lumpur: ISTAC, 1995.

Sya'rawi, Muhammad Mutawally. Tafsir Sya'rawi, terj. Zainal Arifin, et al., Jilid. 4. Medan: Duta Azhar, 2006. 